\section{DESIGN AND PRODUCTION OF EYE PROSTHESIS USING 3D PRINTING}

\begin{abstract}
JOSEF SEDLAK, ONDREJ VOCILKA, MARTIN SLANY, JOSEF CHLADIL, ALES POLZER, MATUS VARHANIK
\end{abstract}

Brno University of Technology, Faculty of Mechanical Engineering, Brno, Czech Republic

DOI : 10.17973/MMSJ.2020_03_2019127

e-mail : sedlak@fme.vutbr.cz

The paper deals with the production of a prototype of aesthetic eye prosthesis using procedures related to reverse engineering technology. Due to the complexity of the prosthesis shape, the 3D model was obtained by scanning a hand-made acrylic prosthesis on the ATOS Compact Scan. Following the pattern of manual production, the model geometry underwent a modification in 3ds Max software, where a planar surface was created in the selected area for the iris texture. By this shape change, the core of the prosthesis prototype was created. Using the UV mapping, the texture of the iris was placed on the surface of the model, which was obtained by modifying a photo from a slit camera. The core of the prosthesis prototype was printed on a full-color 3D printer Stratasys J750, which uses additive Polyjet technology based on the curing of photopolymers. In order to form a biocompatible surface, the printed core was embedded in a clear acrylate in a mold made using an original acrylate prosthesis. The paper concludes with an overall evaluation of the achieved results with a description of problematic production steps and a proposal for a procedure for the future production of prostheses by 3D printing.

KEYWORDS Eye prosthesis, artificial eye, 3D printing, PolyJet, Stratasys J750

\section{INTRODUCTION}

Indications for the use of an ophthalmic prosthesis may be a disease or an accident, resulting in surgery such as enucleation or evisceration to remove the eye. In some cases, a patient who still has a blind eye decides to wear the prosthesis purely for aesthetic reasons. Aesthetic eye prostheses play an essential role in overcoming trauma caused by vision loss. They greatly help them to return to everyday life and improve its quality. To make the process easier, it is crucial that the prosthesis looks as plausible and natural as possible. Eye prosthesis most often serve as an aesthetic replacement of the removed eye and are divided according to function. It is not just an ocular prosthesis replacing the enucleated, eviscerated eye, or complete ectoprosthesis that are used to replace the removed eyeball and surrounding tissues. This includes colored contact lenses for cases where it was not necessary surgery removal and therapeutic or diagnostic dentures, which are used to treat injuries [Dürrová 2007] [Huang 2009] [Kathuria 2012] [Klusoňová 2015] [Pine 2015] [Tošovská 2007].

This paper describes the process of prototype aesthetic eye prosthesis using PolyJet additive technology. The main aim of the experiment was to create a new procedure for making ophthalmic prostheses using modern technologies and thus to improve existing production.

\subsection{Eye aesthetic prostheses}

Currently, eye prostheses are mainly made of acrylate and in Central Europe still made of glass. The beginnings of today's production of glass eye prostheses dates from the first half of the 19th century, when a new glass blowing technique was developed in Germany. Meanwhile, production has also been individualized, instead of manufacturing stock prostheses, custom-made prostheses have begun to be produced for patient needs [Dürrová 2007] [Huang 2009] [Kathuria 2012] [Klusoňová 2015] [Pine 2015] [Tošovská 2007] [Vocílka 2017].

Prostheses made of polymethyl methacrylate (PMMA), commonly known as plexiglass or acrylic glass, began to be manufactured in the 1940s. PMMA has already proven itself in the production of dental prostheses and thus appeared to be an ideal candidate, see Fig. 1. PMMA prostheses were successfully manufactured almost simultaneously in the US and the UK. The material later became available to the public and very quickly gained in popularity, which continues to enjoy today. A great advantage is the possibility of making a prosthesis based on the impression of the eye, which ensures maximum comfort for the patient [Dürrová 2007] [Huang 2009] [Kathuria 2012] [Klusoňová 2015] [Pine 2015] [Tošovská 2007] [Vocílka 2017].

In addition to custom-made prostheses, stock prostheses which are manufactured in a wide range of colors, sizes and shapes are also used. It is a mass production and so their main advantage is especially low price. Due to the unique nature of each patient, their use is very limited. They are used in areas where prosthetics are not available, as they do not require a high level of expertise to adjust them. Another use is as a temporary prosthesis after surgery or application in the arts [Ocular Prosthetics 2019] [Pine 2015] [Sajjad 2012] [Vocílka 2017].

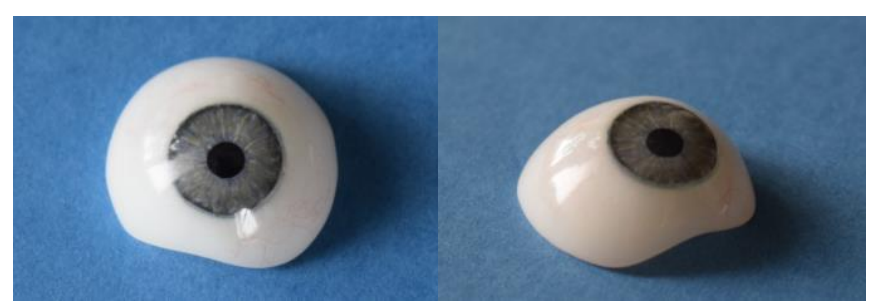

Figure 1. Example of acrylic prosthesis [Vocílka 2017]

\section{EXPERIMENTAL PART}

Due to the shape complexity of the prosthesis, it would be extremely difficult to create a model. Therefore, reverse engineering methods were used [Píška 2009].

[Píska 2009] describes reverse engineering as follows: "Reverse engineering is characterized by the opposite sequence of activities to the classical production process. In the classic process, the designer creates a CAD design of a virtual part model on the basis of the underlying materials, which becomes the template for the production of the physical part. In reverse engineering, there is a physical object at the beginning, which is digitized into model data with which the designer can continue to work with data processing systems as needed."

\subsection{Scanning of PMMA prosthesis}

ATOS Compact Scan which belongs to the group of contactless scanners and operates on the principle of optical digitization was used for scanning. The scanner is designed for 3D measurement and inspection of parts. The use of noncontact scanners is particularly suitable for objects that could 
be damaged by using the contact method. There are several measuring ranges available for the scanner, depending on the projector and capture camera configuration selected. The measuring range then determines the measuring volume in which the object can be scanned. This volume is displayed by the scanner software for better user clarity [Vocílka 2017].

To scan the prosthesis, the ATOS Compact Scan 2M sensor with camera position 300 was used Tab. 1 [Ústav automobilového inženýrství VUT FSI].

\begin{tabular}{|l|l|}
\hline $\begin{array}{l}\text { Measuring volume } \\
\text { Distatnce of the measuring } \\
\text { point }\end{array}$ & $125 \times 90 \times 90 \mathrm{~mm}$ \\
\hline Recomended reference points & $\varnothing 1.5 \mathrm{~mm}$ \\
\hline $\begin{array}{l}\text { Measuring distance } \\
\text { Camera anle }\end{array}$ & $570 \mathrm{~mm}$ \\
\hline Focal length of camera lens & $25^{\circ}$ \\
\hline Focal length of objective lens & $23 \mathrm{~mm}$ \\
\hline
\end{tabular}

Table 1. Basic information about the used scanner measuring range [Ústav automobilového inženýrství VUT FSI]

For successful scanning, the acrylic prosthesis had to be prepared. Due to its glossy surface, it was necessary to apply a chalk coating on its surface. The coating layer must be thick enough to dull the surface, but its thickness should be as small as possible (distortion of the subject may occur) [Sedlák 2017] [Ústav automobilového inženýrství VUT FSI].

The next step was to locate the reference points, by means of which the individual scans are positioned relative to each other. Their size was chosen according to the scanner's measuring range. Due to the complicated geometry of the prosthesis and its small dimensions, it was not possible to fit it into a standard spike scanning frame. The reference points were therefore placed (glued) directly on the prosthesis surface. A total of 26 reference points with a diameter of $1.5 \mathrm{~mm}$ were placed on the acrylic prosthesis. The disadvantage of such a location of the points is the formation of holes that arise during scanning at the points where the reference points are located. These areas had to be closed by software [Sedlák 2017] [Ústav automobilového inženýrství VUT FSI].

Scanning was performed using a rotary table on which the prosthesis was placed. First, the position of the reference points on the upper and lower sides of the prosthesis had to be recorded in the software. It had to be positioned so as to ensure its stable position and to avoid distortion of the mutual position of the points [Sedlák 2017] [Vocílka 2017].

Since it was not possible to place the prosthesis in the frame, it was necessary to use an improvised product. Several reference points were adhered to the fixture, see Fig. 2 . After placing the prepared prosthesis into the fixture, the relative position of the spots was scanned while the stage was rotated. When recording the position of the reference points, the software also assigned an identification number to each of them. This made it possible to remove the prosthesis from the fixture and place it separately on a pad in the center of the rotary table for further scanning, see Fig. 3 [Sedlák 2017] [Vocílka 2017].

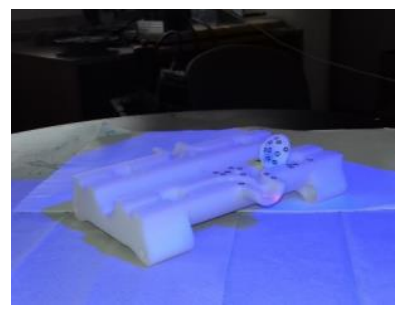

Figure 2. Prosthesis in the jig [Vocílka 2017]

Digitization was performed with a set of scans in the scanner software. After each scan, the turntable was rotated at a specified angle. The size of the angle was chosen such that the number of scanning steps was sufficient with respect to the size of the scanned object and the required quality of the final scan. For successful scanning, it is recommended that each scan camera scans four points (at least 3 ) for each scan. After the table was rotated 360 degrees, the prosthesis was inverted and the scan was repeated for the other side of the object [Sedlák 2017] [Vocílka 2017].

The images have been reviewed to remove potential interference from the surroundings. All images were compiled into the model based on the position of the reference points, and the holes after the reference points were closed. This step resulted in the resulting 3D model of acrylic prosthesis, which was exported in STL (Stereolithography) format [Sedlák 2017] [Vocílka 2017].

\subsection{Creating a prototype core model}

The model was imported into 3Ds Max, which is designed for 3D modeling, animation, rendering and is used in the gaming and film industry [Vocílka 2017].

In order to achieve a better aesthetic result of the final prosthesis, a flat surface for the iris was created on the model, on which the cornea of clear PMMA is placed during final processing, thus creating the required depth of view. The first step was to identify a suitable location for the creation of a planar surface. The most suitable place is naturally the area where the iris was located on the prosthesis used. In this area, by cutting the model, a circular surface was created to accommodate the texture of the iris, see Fig. 4 [Vocílka 2017].

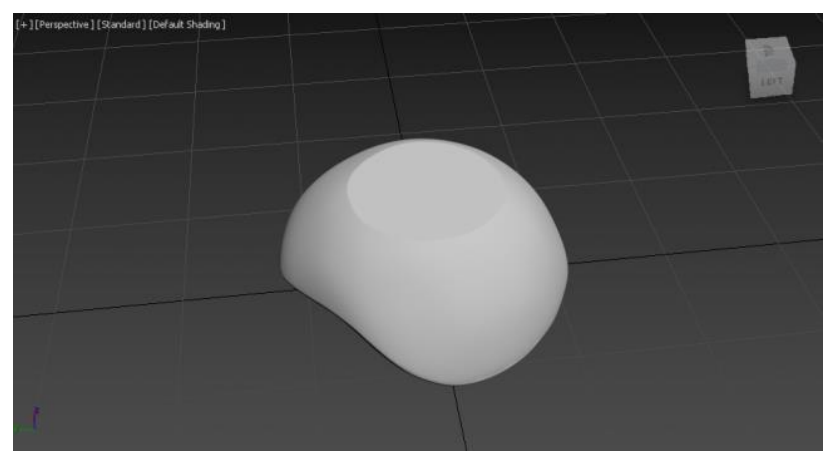

Figure 4. Modified prosthesis model [Vocílka 2017]

\subsection{Application of texture to the prosthesis core}

To obtain the highest quality photo for the texture of the iris and surroundings it was necessary to use specialized equipment. The photograph in Fig. 5 was taken with a slit lamp HAAG-STREIT BX 900 at the Eye Clinic in the University Hospital Brno. The slit lamps allow observation of the anterior segment of the eye, especially the cornea, iris and lens. This device can be directly connected to a computer for direct diagnosis or 
consultation on the monitor. It is also possible to keep records and thus the progress of the disease [Vocílka 2017].

The first adjustment was to remove glare and algae from the iris area. This was followed by a further modification in the area of the eyelids, namely the complete replacement of the colors with whites and the extension of this area. The result was a TIFF image that was used as the basis for the texture, see Fig. 6 [Vocílka 2017].

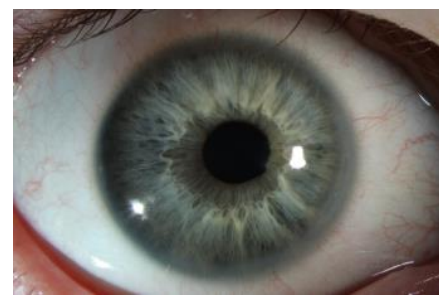

Figure 5. Original photo of eye [Vocílka 2017]

Figure 6. Detail of modified photo [Vocílka 2017]

Fig. 6 was applied to a selected group of polygons at the top of the model using a material editor. By applying the material created on the basis of the photograph to the group of polygons, the upper part of the prosthesis model was colored. UV mapping was used to achieve the desired texture distribution on the model surface. "The mapping coordinates $\mathrm{U}$ and $\mathrm{V}$ determine the direction in which the texture will be aligned with the model. It is an analogy of the object coordinates $\mathrm{X}, \mathrm{Y}$, but for materials (UVW corresponds to $\mathrm{XYZ}$ )" [Kř́iž 2010].

Manipulation with the UV map and its placement at the required coordinates resulted in a colored model of the prosthesis, see Fig. 7 [Vocílka 2017].

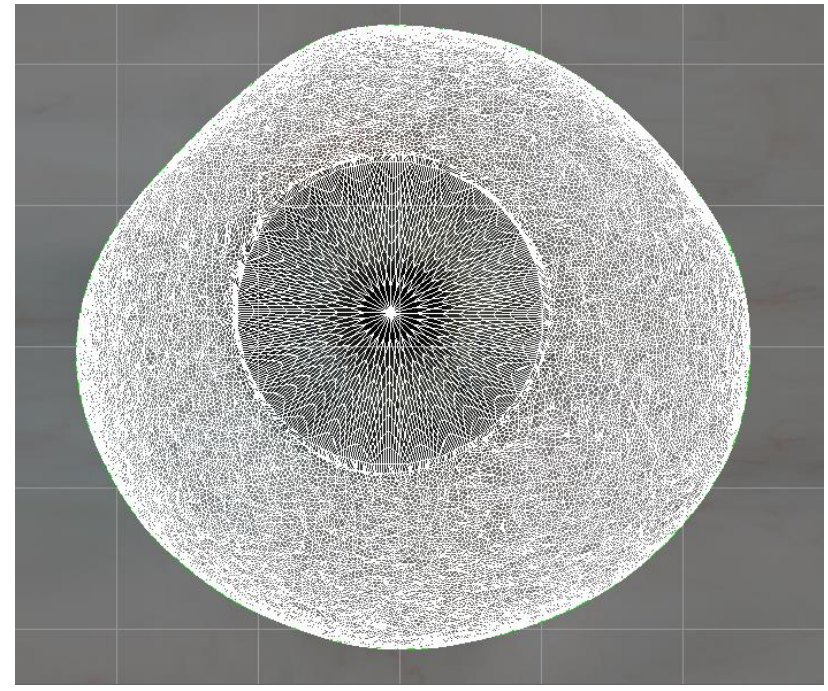

Figure 7. UV map detail [Vocílka 2017]

Texture rendering was performed before exporting to $3 \mathrm{D}$ printing. Using the Texture Renderer, an image as shown in Fig. 8 was created to render the texture only for the area where UV Mapping was performed. To apply the created texture to the model, a new material was created in the material editor, which was then applied to a group of polygons to replace the original material. Pure white material was used for the inverted selection of polygons, especially on the underside of the model. The result of the whole modification was a dyed model of the prosthesis core suitable for export for 3D printing, see Fig. 9 [Vocílka 2017].

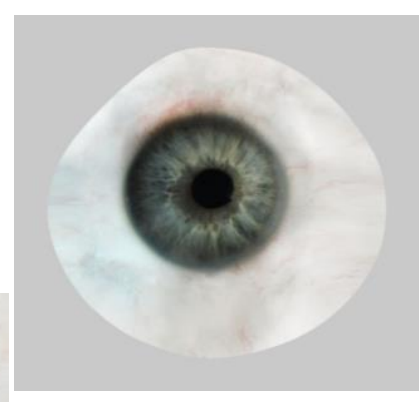

Figure 8. Detail of created texture [Vocílka 2017]

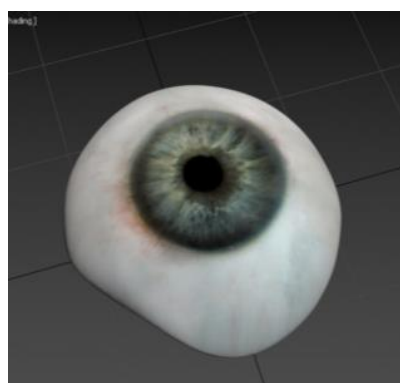

Figure 9. Final image of the prosthesis core model [Vocílka 2017]

\subsection{Printing the prototype core of the prosthesis}

$3 \mathrm{D}$ printing of the prototype took place in the company MCAE Systems, s.r.o. on the Stratasys J750, which uses Polyjet technology. This printer is the fourth generation of PolyJet printers. PolyJet technology, see Fig. 10, was developed by Objet and is one of the Rapid Prototyping methods. This technology enables fast and very accurate production [Vocílka 2017] [Wohlers 2016].

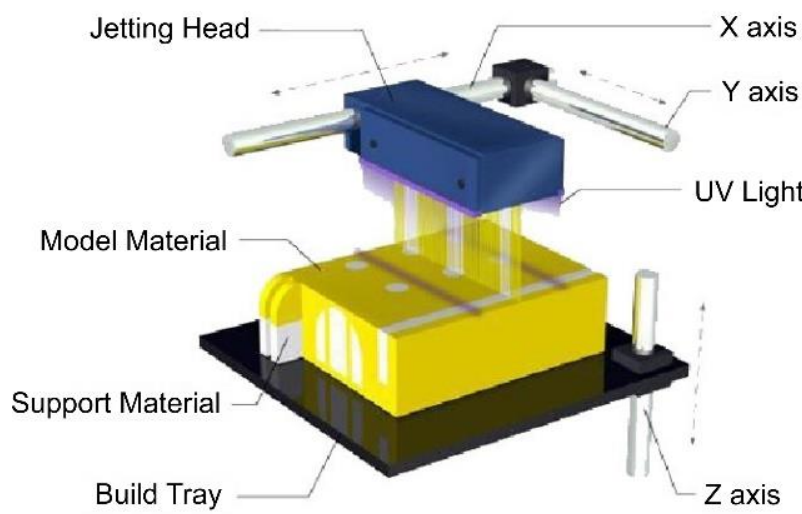

Figure 10. PolyJet technology - according to [3DADDFAB 2019] [Vocílka 2017]

The print head, which contains a large number of nozzles, moves in the $\mathrm{X}$ - and $\mathrm{Y}$-axis and the support plate in the $Z$-axis. Then, the $Z$ axis moves down one layer height. An additional layer is applied to the already cured material and the whole process is repeated until the object is finished. In addition to the building material of the model, a support material is applied, which can be removed manually or using a water jet after completion [Vocílka 2017].

Stratasys $\mathbf{J 7 5 0}$ printer can combine up to 6 different materials, has four times more nozzles than previous Polyjet systems and achieves an accuracy of 20 to 85 microns for objects up to 50mm [MCAE Systems s.r.o.] [Stratasys 2019] [Vocílka 2017].

3D printing can be performed in 3 modes Stratasys [Stratasys 2019]:

$>$ high speed, up to 3 base resins, layer $27 \mu \mathrm{m}$,

$>$ high speed, up to 6 base resins, layer $14 \mu \mathrm{m}$,

$>$ high speed and quality, up to 6 base resins, layer $27 \mu \mathrm{m}$.

Photopolymers can be placed in the material slots to create a CMYK color model, and white and transparent material can be installed in the remaining two locations. Thanks to such 
combination the 3D printer is capable of producing more than 360,000 shades of color. It is also possible to combine materials of different elasticity. Biocompatible materials are also available, for example in dental restorations [Vocílka 2019].

This 3D printer is one of the most advanced tools for Rapid Prototyping and can create a fully colored model. Thanks to these features, it is ideal for 3D printing of such a colorintensive prototype. For 3D printing, the highest quality printing mode has been chosen, with a layer height of $14 \mu \mathrm{m}$ and all 6 materials can be used. Parameters of 3D printing in the given mode are shown in Tab. 2 [MCAE Systems s.r.o.] [Design with brililiance 2016] [Sedlák 2016] [Stratasys 2019] [Vocílka 2019] [3DADDFAB 2019].

\begin{tabular}{|l|l|}
\hline Print time & $1 \mathrm{hr} 22 \mathrm{~min}$ \\
\hline Building material weight & 14 grams \\
\hline Weight of support material & 9 grams \\
\hline
\end{tabular}

Table 2. 3D printing parameters [Vocílka 2017]

After the 3D printing the support material was removed from the printout creating the core of the prototype itself, see Fig. 11 [Vocílka 2017].

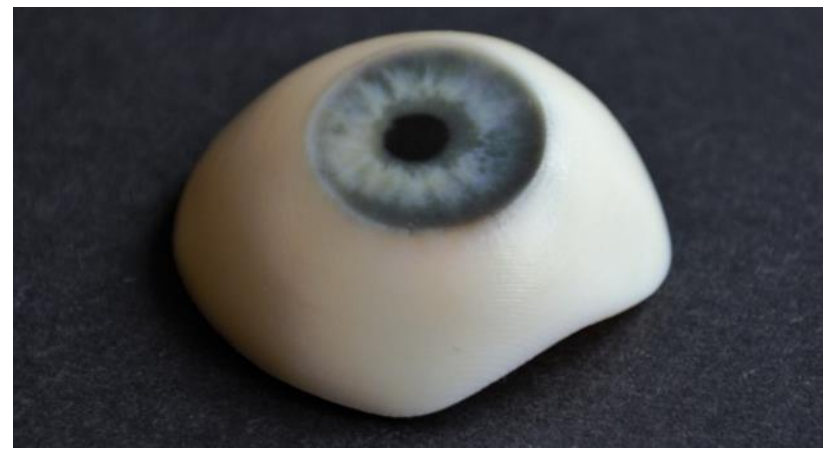

Figure 11. Printed prototype core after removing supports [Vocílka 2017]

\subsection{Aplication of PMMA layer on the prosthesis core}

In order to achieve the health safety of the resulting prototype, it was necessary to apply a biocompatible layer to the surface of the prosthesis. For this purpose, a similar process was chosen as in the case of hand-made production by casting a thin layer of clear PMMA. Due to the necessary equipment, this process took place in the laboratory of Mr. Klíčníková, which is engaged in the production of acrylic prostheses [Vocílka 2017].

In order to achieve a better aesthetic effect, an additional veining of combed red cotton was placed on the core surface as in the case of handmade. The original prosthesis, which was used for scanning, was also used for mold making, see Fig. 12 for PMMA casting. This was slightly modified after curing to suit the printed core. The first application attempt was unsuccessful because there was a problem with the acrylic adhering to the core surface and peeling it off. Thus, prior to the second attempt, the core surface was ground, the veins were placed again and embedded in acrylate. The resulting surface was then polished, thus completing the prototype modifications, see Fig. 13. The entire process took about 4 hours. Because of the time and difficulty of the entire PMMA application process, this procedure was only tested on the front of the prosthesis, which is sufficient to demonstrate the result [Vocílka 2017].

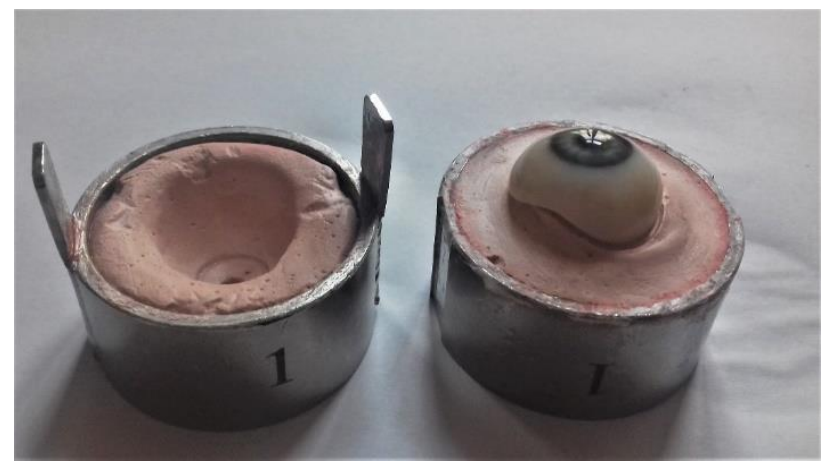

Figure 12. PMMA casting mold with prototype is sufficient after surface treatment [Vocílka 2017]

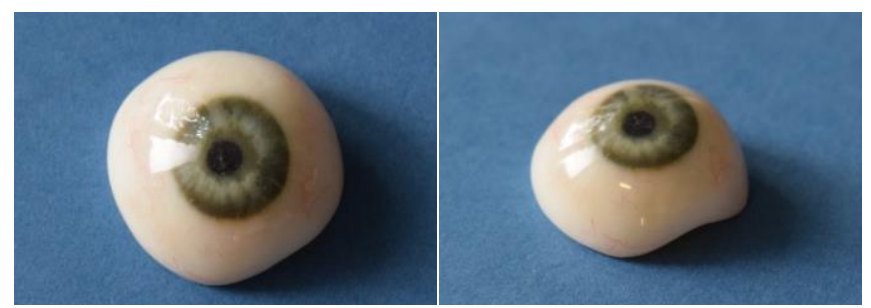

Figure 13. Prototype with sufficient surface treatment [Vocílka 2017]

\section{DISCUSSION}

\subsection{Evaluation of the prosthesis and operations performed}

Preparing the prosthesis for scanning was, due to its size and shape, difficult to place reference points and surface finish. By providing a suitable fixture to secure the prosthesis during scanning, this operation can be greatly streamlined. There was no significant complication in the prosthesis scan itself [Vocílka 2017].

Creating the iris surface on the model obtained from the scan performed in 3ds Max was very complicated and time consuming. Likewise, the location and orientation of the surface so as to create a natural viewing direction is difficult to realize in this way. For further production, it would be preferable to use a hand-made semi-finished product which already has an iris surface for scanning as a stepping stone for further processing [Vocílka 2017].

The printout of the prosthesis core, especially the iris region, demonstrates the suitability of using 3D printing for the production of aesthetic eye prostheses and its great potential in this area. The iris is very plausible, matches the used photo and creates a natural look. However, the conjunctival of the conjunctiva, which is visible on the exported model, see Fig. 8, was too detailed for 3D printing (for more 3D printing it would be useful to try a more pronounced texture) [Vocílka 2017].

A particularly problematic step was the application of acrylate. Despite the successful operation, the results of this finishing method are highly uncertain due to the sensitivity of the photopolymer used to higher temperatures (recommended maximum values are 45 to $50 \circ \mathrm{C}$ ). The temperature occurring during PMMA watering is $120^{\circ} \mathrm{C}$, and this operation may cause deformation of the shape. Another disadvantage is the time required to manufacture the mold and the casting itself. It is therefore advisable to use a different method for achieving surface health [Design with brililiance 2016] [Vocílka 2017]. 


\subsection{Proposal of future procedure for production of customized prostheses by $3 D$ printing}

The first step would be to scan a set of handmade semi-finished models. These blanks have a flat area in the region of the iris location, and this area would make it easier to both scan and adjust and then stain in the program. With this set of models, you can easily create a cornea sized to match the iris diameter. This would be placed on the respective area and this would result in the final shape of the prosthesis. The shape can then be easily modified, by adding a thin layer around the entire volume, to create a new object that would become the envelope for the prosthesis core. This packaging would be made of transparent material in print [Vocílka 2017].

The prostheses consisting of the core and the corresponding casing would be printed and would only undergo a surface treatment after removal of the supports. This would create a basic set of prostheses. From this set, the patient would, as in the glass prosthesis manufacturing process, choose a suitable shape [Vocílka 2017].

The program would then adjust the location of the iris area on the nucleus that belongs to the patient-selected prosthesis. The next stage would be the coloring of the textures produced and the finishing of the packaging, just like the basic set of prostheses. The shape of the resulting prosthesis, outside the iris region, would perfectly match the model. This would ensure that the prosthesis would suit the patient. Another advantage would be that each 3D model of the prosthesis can be saved, creating a patient database. If the patient's current shape of the prosthesis suits the patient, it would not be necessary to repeat the procedure after the end of his life. Only $3 \mathrm{D}$ printing and surface treatment of the prosthesis could be sent to the patient [Vocílka 2017].

The above procedure is already technically feasible, but needs to be tested. Similarly, the color stability and resistance of the material to the environment in the eye socket should be tested to determine the durability of such a prosthesis [Vocílka 2017].

A major problem is the biocompatibility of the printed prosthesis, which remains unresolved. Stratasys offers materials designed for PolyJet printers for medical applications. These are resins used for dental restorations, but the use of these materials in the manufacture of ocular prostheses has not been tried [Vocílka 2017].

\subsection{Economic evaluation of the prototype}

The total cost of 3D printing of the prototype core was calculated according to (1) based on the rate of $€ 19.60$ per hour of printing, building material price of $€ 0.31$ per gram, support material price of $€ 0.20$ per gram, and Tab. 2 values [Vocílka 2017].

$$
C_{j}=\mathrm{T}_{\mathrm{h}} * \mathrm{t}+\mathrm{C}_{\mathrm{sm}} * \mathrm{~m}_{\mathrm{sm}}+\mathrm{C}_{\mathrm{pm}} * \mathrm{~m}_{\mathrm{pm}}
$$

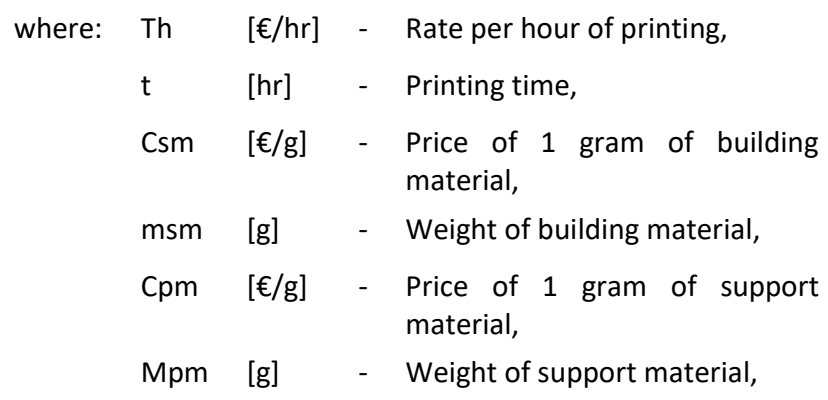

$$
C_{j}=19.60 * 1.37+0.31 * 14+0.20 * 9=32.99 €
$$

The calculation of the resulting amount shows that more than $80 \%$ of the financial cost of production is the operation of a 3D printer. It should be noted, however, that in multi-piece production, printing time does not increase significantly, thus reducing the cost per 3D printer operation [Vocílka 2017].

The total cost of prototype production was calculated according to formula (2). The cost of applying the PMMA layer and making the mold was estimated at $€ 70.44$. These financial costs are another reason to avoid this method [Vocílka 2017].

$$
\mathrm{C}=C_{j}+\mathrm{C}_{\mathrm{ap}}
$$

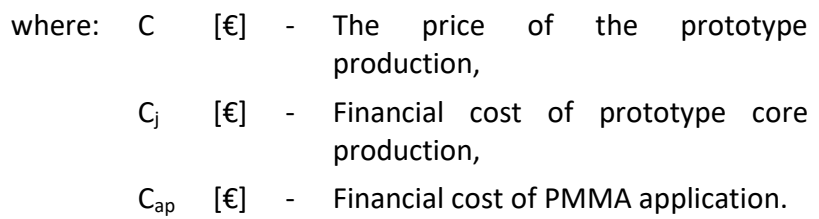

\section{$C=32.99+70.44=103.43 €$}

The price of one glass prosthesis in the Czech Republic is around $78 €$ and the price of acrylic prostheses is approximately $115 €$. Therefore, the total cost of prototype production is similar to that of handmade prostheses in the Czech Republic. However, this price includes only the cost of material and operation of the 3D printer. Including other items, such as modifying the model or license price of the software used, the real price would be significantly higher [Vocílka 2017].

However, production abroad could be more interesting, for example, in the UK, the cost of handmade prostheses is up to $f 3000$ (approximately $€ 3465$ ). In 2013, a project dealing with 3D printing of eye prostheses in larger numbers was created in cooperation with Fripp Design and Research and Manchester Metropolitan University. The cost of the prosthesis they design is around $€ 100$ (about $€ 116$ ). However, these were not made-to-measure prostheses for patients, but mass production of prostheses at the level of stock prostheses [Vocílka 2017].

\section{CONCLUSIONS}

The main aim of the experiment was to design and manufacture a prototype of aesthetic eye prosthesis based on a 3D model obtained by scanning acrylic prosthesis and its production using additive PolyJet technology. The printed core of the prototype achieves considerable aesthetic qualities especially in the iris region. The overall appearance after the application of veined cotton and acrylic coating is comparable to handmade prostheses.

When evaluating the manufactured prototype from the economic point of view, the cost of its production exceeded the price of prostheses manufactured in the Czech Republic. The most important and unresolved problem remains the health safety of the printed prototype. The goal in continuing this experiment will be to produce a replacement using only $3 \mathrm{D}$ 
printing without the additional PMMA application. The experiment has brought important knowledge for the process and production of aesthetic eye prostheses in the future using modern additive technology.

\section{ACKNOWLEDGMENTS}

This research work was supported by the Brno University of Technology, Faculty of Mechanical Engineering, Specific research 2019, with the grant " Research of perspective production technologies ", FSI-S-19-6014.

\section{REFERENCES}

[BENIAK 2015] BENIAK, J., KRIZAN, P., MATUS, M., A comparison of the tensile strength of plastic parts produced by a fused deposition modeling device, (2015) Acta Polytechnica, 55 (6), pp. 359-365. DOI: 10.14311/AP.2015.55.0359.

[DESIGN WITH BRILLIANCE 2016] Design With Brilliance [online]. Eden Prairie: Stratasys, 2016 [cit. 2019-10-27]. Dostupné $\mathrm{z}$ : http://www.stratasys.com/landing/stratasys_j750_ebook [DURROVA 2007] DURROVA, A. Ocni protetika - indikace k uziti ocních protez [online]. Brno, 2007 [cit. 2019-10-19]. Dostupne z: https://is.muni.cz/th/rtp8s/. Diplomova prace. Masarykova univerzita, Lekarska fakulta. Vedouci práce Sylvie Petrova.

[HUANG 2009] HUANG, D. et al. A Modified Evisceration Technique with Scleral Quadrisection and Porous Polyethylene Implantation. American Journal of Ophthalmology. 2009-05, vol. 147, no. 5, p. 924-928.e3. DOI: 10.1016/j.ajo.2008.11.022.

[KATHURIA 2012] KATHURIA, N. et al. A modified technique and simplified laboratory procedure for Ocular Prosthesis Fabrication. Journal of Prosthodontic Research. 2012-04, vol. 56, no. 2, p. 147-150. DOI: 10.1016/j.jpor.2011.07.002.

[KLUSONOVA 2015] KLUSONOVA, L. Ocni protezy [online]. Brno, 2015 [cit. 2019-04-19]. Dostupné z: https://is.muni.cz/th/cvflf/. Bakalarska prace. Masarykova univerzita, Lekarska fakulta. Vedoucí prace Sylvie Petrova.

[KRIZ 2010] KRIZ, J. Mistrovstvi v 3ds Max. Brno: Computer Press, a.s., 2010. ISBN 978-80-251-2464-2.

[MCAE SYSTEMS, S.R.O.] MCAE Systems, s.r.o. [online]. Kuřim: MCAE Systems, b.r. [cit. 2017-10-27]. Dostupné z: http://www.mcae.cz/cs/uvod/

[OCULAR PROSTHETICS 2019] The Difference Between a Stock and Custom Prosthetic Eye. Ocularpro [online]. Los Angeles: Ocular Prosthetics, Inc., 2019 [cit. 2019-10-27]. Dostupné z: http://ocularpro.com/the-difference-between-a-stock-andcustom-prosthetic-eye/

[PINE 2015] PINE, K., SLOAN, B., JACOBS, R. Clinical Ocular Prosthetics [online]. Cham: Springer International Publishing, 2015 [cit. 2017-05-01]. ISBN ISBN 978-3-319-19057-0. Dostupné z: http://www.springer.com/it/book/9783319190563

[PISKA 2009] PISKA, M. Speciální technologie obrabeni. Vyd. 1. Brno: Akademické nakladatelství CERM, 2009. ISBN 978-80-2144025-8.

[SAJJAD 2012] SAJJAD, A. Ocular Prosthesis: A Simulation of Human Anatomy: A Literature Review [online]. b.r. [cit. 27.10.2019]. Dostupné z: http://www.cureus.com/articles/1356-ocular-prosthesis---asimulation-of-human-anatomy-a-literaturereview\#.VDWBO_I_u2B

[SEDLAK 2016] SEDLAK, J., BACHORIK, P., JAROS, A., POLZER, A., KALIVODA, M. Application of Modern Technologies in
Production Design of Car Component Prototype. MM Science Journal, 2016, vol. 2016, no. 5, p. 1387-1391. ISSN 1803-1269.

[SEDLAK 2017] SEDLAK, J., POLZER, A., CHLADIL, J., SLANY, M., JAROS, A. Reverse Engineering Method Used for Inspection of Stirrer' s Gearbox Cabinet Prototype. MM Science Journal, 2017, vol. 2017, no. 4, p. 1877-1882. ISSN 1803-1269.

[STRATASYS 2019] Stratasys [online]. Eden Prairie: Stratasys, 2019 [cit. 2019-05-24]. Dostupné z: http://www.stratasys.com/ [TOSOVSKÁ 2007] TOSOVSKA, D. Oční protézy [online]. Brno, 2007 [cit. 2019-04-17]. Dostupné z: https://is.muni.cz/th/t54a2/. Bakalářská práce. Masarykova univerzita, Lékařská fakulta. Vedoucí práce Jan Richter.

[USTAV AUTOMOBILOVEHO INZENYRSTVI VUT FSI ] ÚSTAV AUTOMOBILOVÉHO INŽENÝRSTVÍ VUT FSI, . Skenování S 3D skenerem [online]. Brno: I, b.r. [cit. 2019-10-27]. Dostupné z: http://www.iae.fme.vutbr.cz/userfiles/ramik/files/Studium/Po dklady\%20ke\%20studiu/3D\%20skenov\%C3\%A1n\%C3\%AD/Elearning-Skenovani\%203D\%20skenerem.pdf

[VOCILKA 2017] VOCÍLKA, O. Návrh a výroba oční protézy 3D tiskem. Brno, 2017, 38 s. Bakalářská práce. Vysoké učení technické $v$ Brně, Fakulta strojního inženýrství. Vedoucí práce Doc. Ing. Josef Sedlák, Ph.D.

[WOHLERS 2016] WOHLERS, T. T., ASSOCIATES, W., CAMPBELL, R. I., CAFFREY, T. Wohlers Report 2016: 3D Printing and Additive Manufacturing State of the Industry: Annual Worldwide Progress Report. 1. vyd. Fort Collins: Wohlers Associates, 2016. ISBN 978-0-9913332-2-6.

[3DADDFAB 2019] 3DAddFab - Powered by Objet Polyjet Technology. 3DAddFab [online]. 2019 [cit. 2019-10-27]. Dostupné z: http://www.3daddfab.com/technology/

\section{CONTACTS}

Assoc. Prof. Josef SEDLAK, Ph.D., MSc.

Brno University of Technology, Faculty of Mechanical Engineering

Institute of Manufacturing Technology, Department of Machining Technology

Technická 2896/2, 61669 Brno, Czech Republic, +420 541142 408, sedlak@fme.vutbr.cz, https://www.vutbr.cz/lide/josef-sedlak-16690

MSc. Ondrej VOCILKA

Brno University of Technology, Faculty of Mechanical Engineering

Institute of Manufacturing Technology, Department of Machining Technology

Technická 2896/2, 61669 Brno, Czech Republic, 171092@vutbr.cz

MSc. Martin SLANY, Ph.D.

Brno University of Technology, Faculty of Mechanical Engineering Institute of Manufacturing Technology, Department of Machining Technology

Technická 2896/2, 61669 Brno, Czech Republic, +420 541142 420, slany.m@fme.vutbr.cz, https://www.vutbr.cz/lide/martin-slany-16898

Assoc. Prof. Josef CHLADIL, CSc., MSc.

Brno University of Technology, Faculty of Mechanical Engineering

Institute of Manufacturing Technology, Department of Machining Technology

Technická 2896/2, 61669 Brno, Czech Republic, +420 541142 557, chladil@fme.vutbr.cz, 
https://www.vutbr.cz/lide/josef-chladil-660

MSc. Ales POLZER, Ph.D.

Brno University of Technology, Faculty of Mechanical

Engineering

Institute of Manufacturing Technology, Department of

Machining Technology

Technická 2896/2, 61669 Brno, Czech Republic,

+420541 142 545, polzer@fme.vutbr.cz,

https://www.vutbr.cz/lide/ales-polzer-16105

MSc. Matus VARHANIK

Brno University of Technology, Faculty of Mechanical

Engineering

Institute of Manufacturing Technology, Department of

Machining Technology

Technická 2896/2, 61669 Brno, Czech Republic,

+421905670531 Matus.Varhanik@vutbr.cz 